\title{
Clinical simulation in nursing education in intensive therapy: an integrative review
}

\author{
Simulação clínica na educação de enfermagem em terapia intensiva: revisão integrativa \\ Simulación clínica en la educación en enfermería en terapia intensiva: revisión integradora
}

\author{
Amanda Chlalup Linn' \\ ORCID: 0000-0001-9125-7423
}

Rita Catalina Aquino Caregnato'

ORCID: 0000-0001-7929-7676

Emiliane Nogueira de Souza'

ORCID: 0000-0002-3873-4304

'Centro Universitário Ritter dos Reis. Porto Alegre, Rio Grande do Sul, Brazil.

How to cite this article: Linn AC, Caregnato RCA, Souza EM. Clinical simulation in nursing education in intensive therapy: an integrative review. Rev Bras Enferm. 2019;72(4):1061-70. doi:http://dx.doi.org/10.1590/0034-7167-2018-0217

Corresponding Author:

Amanda Chlalup Linn

E-mail: amandalinn21@gmail.com

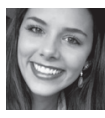

Submission: 05-10-2018 Approval: 09-18-2018 ABSTRACT
Objective: to analyze the publications on clinical simulation practices for education in
Nursing in Intensive Care. Method: an integrative review carried out through LILACS,
PubMed, Cochrane Library, CINAHL and SciELO databases, of articles published from
2008 to 2017 . Results: 29 articles were selected, of which $76 \%$ discuss the use of
simulation in continuing education of nursing professionals, while the others describe
their use for student education. There is a higher prevalence of studies with a level of
evidence 6 (17), with 28 international publications. There was an increase in scientific
production, with 16 articles published in the last three years. Conclusion: variables after
simulation use, such as confidence, communication skills, efficiency in the identification
of clinical worsening of patients, development of technical skills, teamwork and clinical
decision-making, presented a significant improvement, demonstrating that this tool is
effective in qualifying care for critical patients.
Descriptors: Nursing; Nursing Education; Patient Simulation; Simulation Training; Critical Care.

\section{RESUMO}

Objetivo: analisar as publicações sobre práticas de simulação clínica para a educação em Enfermagem em Terapia Intensiva. Método: revisão integrativa realizada através da biblioteca LILACS, PubMed, The Cochrane Library, CINAHL e SciELO, de artigos publicados de 2008 a 2017. Resultados: foram selecionados 29 artigos. 76\% abordaram o uso da simulação na educação continuada de profissionais de enfermagem, enquanto os outros descrevem seu uso para a educação de estudantes. Há uma maior prevalência de estudos com nível de evidência 6 (17), sendo 28 publicações em âmbito internacional. Verificouse uma crescente na produção científica, sendo 16 artigos publicados nos três últimos anos. Conclusão: as variáveis, após o uso da simulação, como confiança, habilidade de comunicação, eficiência na identificação da piora clínica de pacientes, desenvolvimento de competências técnicas, trabalho em equipe e tomada de decisão clínica, apresentaram um aperfeiçoamento significativo, demonstrando que essa ferramenta é efetiva na qualificação da assistência a pacientes críticos.

Descritores: Enfermagem; Simulação; Simulação de Paciente; Educação em Enfermagem; Cuidados Críticos.

\section{RESUMEN}

Objetivo: analizar las publicaciones sobre prácticas de simulación clínica para la educación en Enfermería en Terapia Intensiva. Método: revisión integradora realizada en la biblioteca LILACS, PubMed, Cochrane Library, CINAHL y SciELO, de artículos publicados de 2008 a 2017. Resultados: se seleccionaron 29 artículos. 76\% abordaran el uso de la simulación en la educación continuada de profesionales de enfermería, mientras que los demás describen su uso para la educación de estudiantes. Hay una prevalencia más grande de estudios con nivel de evidencia 6 (17), siendo 28 publicaciones a nivel internacional. Se verificó una creciente en la producción científica, siendo 16 artículos publicados en los tres últimos años. Conclusión: las variables, después del uso de la simulación, como confianza, habilidad de comunicación, eficiencia en la identificación del empeoramiento clínico de pacientes, desarrollo de competencias técnicas, trabajo en equipo y toma de decisión clínica presentaron un perfeccionamiento significativo, demostrando que esa herramienta es efectiva en la calificación de la asistencia a pacientes críticos.

Descriptores: Enfermería; Simulación; Simulación de Paciente; Educación en Enfermería; Cuidados Críticos. 


\section{INTRODUCTION}

Nursing care, related to safe and effective care, demands interpretation of human responses accurately, selection of appropriate interventions and evaluation of the results achieved ${ }^{(1)}$, in other words, the use of clinical reasoning as a fundamental tool for the nurses' work, which must be developed from undergraduate and, permanently, in Health Education ${ }^{(2)}$. In this context, the development of clinical reasoning for an accurate practice should be intrinsically related to the use of different teaching strategies in the course of vocational training ${ }^{(3)}$.

In the scope of active teaching methodologies in Health, the clinical simulation is highlighted ${ }^{(4)}$. Simulation represents a technology used to recreate real life situations, being a vehicle for generating clinical reasoning ${ }^{(5)}$. This tool has demonstrated effectiveness in the development of critical thinking ${ }^{(6)}$, development of skills ${ }^{(7)}$, decision-making ${ }^{(8)}$, teamwork and strengthening self-confidence ${ }^{(9)}$.

In training of nurses, clinical simulation has been used as an effective and innovative teaching strategy. Through this methodology, nursing students and professionals have learning and training subsidies, having access to an extended relationship between theory and practice in a safe environment ${ }^{(10)}$. In practice, clinical simulation emerges as a profitable strategy and is capable of increasing teaching-learning technologies, making it possible to carry out important clinical studies within the framework of safe practices, in promotion of ethical attitudes and professional and interdisciplinary responsibility in care for the patient, family and community ${ }^{(11)}$.

Intensive Care Unit (ICU) is a highly complex work environment and thus requires professionals with advanced skills to care for critically ill patients ${ }^{(12)}$. Nursing education in intensive care represents a great challenge for students, professors and health professionals. They deal with the complex health situation of the patients in the care setting, and must exercise the articulation of theoretical knowledge with practice, development of capacity for more accurate perception and rapid and informed decision-making ${ }^{(6)}$. Considering the specificities of this setting, it is the way in which the incorporation of clinical simulation, during the professional training, can increase quality to the care offered by professionals graduating from the undergraduate.

\section{OBJECTIVE}

To analyze publications on clinical simulation practices used in Nursing Education in Intensive Care, at national and international level, considering the use and strengthening of this innovative teaching methodology in nursing for the qualification of students and professionals of the field.

\section{METHOD}

It is an integrative review of the literature, using a research method used in evidence-based practice, which allows the incorporation of these in clinical practice $^{(13)}$. This method has the purpose of gathering and synthesizing research results on a delimited topic or issue, in a systematic and orderly manner, contributing to the deepening of the knowledge of the researched topic ${ }^{(14-15)}$.

The guiding question of the review, carried out through the PICO strategy ${ }^{(16)}$ was: how has clinical simulation been used in nursing education directed to Intensive Care? It was considered the strategic PICO, in which the population $\mathrm{P}$, in this study, corresponds to Nursing (professionals and students); I to intervention, considering the clinical simulation in Intensive Care; and co from context.

In order to answer the research question, a selection of the controlled descriptors related to each of the components of the PICO strategy was carried out, according to the Health Sciences Descriptors (DeCs) and Medical Subject Headings (MeSH). The controlled descriptors and Boolean operators were selected: Nursing students OR Nurse practitioners OR Nursing education OR Professional Education AND Critical care OR Critical care nursing AND Patient Simulation OR Simulation training.

The data were collected through the search of articles indexed in databases and libraries referring to Latin American \& Caribbean Literature in Health Sciences (LILACS), National Library of Medicine (PubMed), The Cochrane Library, Scientific Electronic Library Online (SciELO), Cumulative Index to Nursing and Allied Health Literature (CINAHL).

The studies published in national and international journals in full, with indexation in the Portuguese, English and Spanish, publications made between 2008 and 2017, identified by the Boolean descriptors and terms in the title or abstract. Those who did not respond to the question of research and publications focusing on pediatrics were excluded from the study. The flow followed to define the sample of the selected articles is shown in Figure 1.

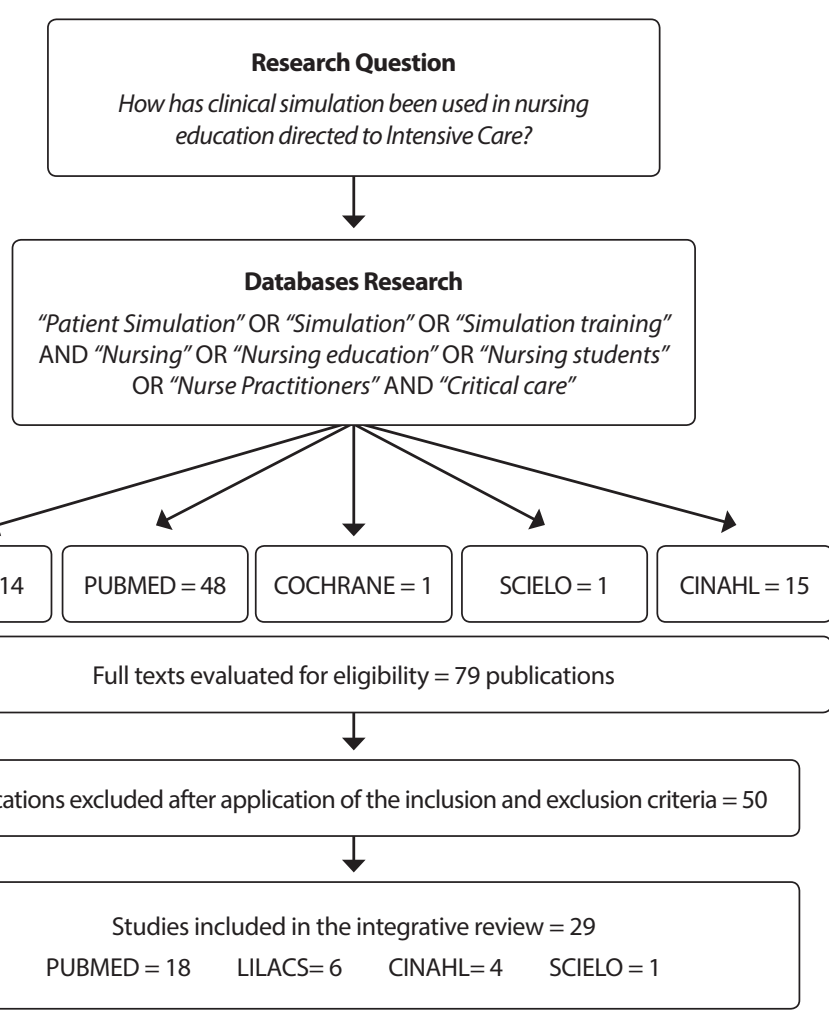

Figure 1- Sample's flow 
In the data collection, a detailed tool was used containing: title, journal, authors, publication year, objectives, methodology, results and conclusions. After that, the analysis and synthesis of the articles obtained in a descriptive way. For the evaluation of level of evidence of the studies, the Rating System for the Hierarchy of Evidence for Intervention/Treatment Questions scale, provided in Figure $2^{(17)}$.

\section{RESULTS}

Twenty-nine publications were selected, predominantly English (28), with 11 publications originating in the United States, six in Finland, three in England, two in Canada, two in Norway, two in Australia, one in Spain, one in Spain in Japan and one in Brazil.

Chart 1 shows the profile of the sample studies and Chart 2, the respective objectives and the conclusions of the studies analyzed.

There was a higher prevalence of evidence-based studies 6 (17), followed by level 2 (05), level 3 (04), level 7 (02) and level 1 (01). There is a growing number of scientific production related to the topic, with 16 articles published in the last three years ${ }^{(18-33)}$, making up 55\% of the searches found in the selected period.

It can be observed in Chart 2 that $34.5 \%$ of the studies are referenced to the use of simulation in education on care techniques of nursing activities, such as mechanical ventilation and invasive airway acquisition, cardiopulmonary resuscitation, oral hygiene and airway aspiration, hand hygiene and delirium identification in ICU patients ${ }^{(21-26,29-31,36)}$.

About training, $76 \%$ of the articles $s^{(18,21-26,28-39,43-46)}$ discuss the use of simulation in continuing education of nursing professionals, while the other studies describe the use of simulation for the education of nursing students ${ }^{(19-20,25,27,40-42)}$.

A study deals with the professional qualification for air transportation of critical patients through simulation ${ }^{(31)}$ and another study presents simulation setting for evaluating the effectiveness of nursing care and the time spent in each critical care task ${ }^{(35)}$.

Chart 1 - Characterization of articles on clinical simulation in Nursing Education in Intensive Care, published in the period between 2008 and 2017

\begin{tabular}{|c|c|c|c|c|}
\hline Author(s), Title & Year & Journal & Method & $\begin{array}{l}\text { Level of } \\
\text { Evidence }\end{array}$ \\
\hline $\begin{array}{l}\text { Crowe S, Ewart L, Derman } S^{(18)} \\
\text { The impact of simulation based education on nursing confidence, } \\
\text { knowledge and patient outcomes on general medicine units. }\end{array}$ & 2017 & $\begin{array}{l}\text { Nurse Education in } \\
\quad \text { Practice }\end{array}$ & $\begin{array}{c}\text { Descriptive } \\
\text { developmental }\end{array}$ & L6 \\
\hline $\begin{array}{l}\text { Sánchez-Expósito J, Costa CL, Agea JLD, Izquierdo MDC, Rodríguez DJ(19) } \\
\text { Ensuring relational competency in critical care: Importance of nursing } \\
\text { students' communication skills. }\end{array}$ & 2017 & $\begin{array}{l}\text { Intensive and Critical } \\
\quad \text { Care Nursing }\end{array}$ & $\begin{array}{l}\text { Cross-sectional cohort } \\
\text { study }\end{array}$ & L3 \\
\hline $\begin{array}{l}\text { Karlsen MW, Gabrielsen AK, Falch AL, Stubberud DG } \\
\text { Intensive care nursing students' perceptions of simulation for learning } \\
\text { confirming communication skills: a descriptive qualitative study. }\end{array}$ & 2017 & $\begin{array}{l}\text { Intensive and Critical } \\
\text { Care Nursing }\end{array}$ & $\begin{array}{l}\text { Qualitative, } \\
\text { exploratory and } \\
\text { descriptive }\end{array}$ & L6 \\
\hline $\begin{array}{l}\text { McRae ME, Chan A, Hulett R, Lee AJ, Coleman } B^{(21)} \\
\text { The effectiveness of and satisfaction with high-fidelity simulation to teach } \\
\text { cardiac surgical resuscitation skills to nurses. }\end{array}$ & 2017 & $\begin{array}{l}\text { Intensive and Critical } \\
\text { Care Nursing }\end{array}$ & Descriptive study & L6 \\
\hline $\begin{array}{l}\text { Smith JM, Van Aman MN, Schneiderhahn ME, Edelman R, Ercole PM } \mathrm{PM}^{(22)} \\
\text { Assessment of delirium in Intensive Care Unit patients: educational } \\
\text { strategies. }\end{array}$ & 2017 & $\begin{array}{l}\text { The Journal } \\
\text { of Continuing } \\
\text { Education in Nursing }\end{array}$ & $\begin{array}{c}\text { Descriptive } \\
\text { developmental }\end{array}$ & L6 \\
\hline $\begin{array}{l}\text { Jansson MM, Syrjala HP, Ohtonen PP, Merilainen } \mathrm{MH} \text {, Kyngas HA, Ala-Kokko T(23) } \\
\text { Effects of simulation education on oral care practices: a randomized controlled } \\
\text { Trial. }\end{array}$ & 2017 & Nursing Critical Care & $\begin{array}{l}\text { Randomized clinical } \\
\text { trial }\end{array}$ & L2 \\
\hline $\begin{array}{l}\text { Jansson MM, Syrjala HP, Ohtonen PP, Merilainen MH, Kyngas HA, Ala-Kokko T(24) } \\
\text { Longitudinal effects of single-dose simulation education with structured } \\
\text { debriefing and verbal feedback on endotracheal suctioning knowledge and } \\
\text { skills: A randomized controlled Trial. }\end{array}$ & 2017 & $\begin{array}{l}\text { American Journal of } \\
\text { Infection Control }\end{array}$ & $\begin{array}{l}\text { Randomized clinical } \\
\text { trial }\end{array}$ & L2 \\
\hline $\begin{array}{l}\text { Gordon CJ, Jorm C, Shulruf B, Weller J, Currie J, Lim R, Osomanski A }{ }^{(25)} \\
\text { Development of a self-assessment teamwork tool for use by medical and } \\
\text { nursing students. }\end{array}$ & 2016 & $\begin{array}{l}\text { BMC Medical } \\
\text { Education }\end{array}$ & $\begin{array}{l}\text { Descriptive } \\
\text { quantitative (unclear } \\
\text { methodology) }\end{array}$ & L6 \\
\hline $\begin{array}{l}\text { Jansson MM, Syrjala HP, Ohtonen PP, Merilainen } \mathrm{MH} \text {, Kyngas HA, Ala-Kokko T(26) } \\
\text { Simulation education as a single intervention does not improve hand hygiene } \\
\text { practices: a randomized controlled follow-up study. }\end{array}$ & 2016 & $\begin{array}{l}\text { American Journal of } \\
\text { Infection Control }\end{array}$ & $\begin{array}{l}\text { Randomized clinical } \\
\text { trial }\end{array}$ & L2 \\
\hline
\end{tabular}


Chart 1 (concluded)

\begin{tabular}{|c|c|c|c|c|}
\hline Author(s), Title & Year & Journal & Method & $\begin{array}{l}\text { Level of } \\
\text { Evidence }\end{array}$ \\
\hline $\begin{array}{l}\text { Lavoie P, Cossette S, Pepin J(27) } \\
\text { Testing nursing students' clinical judgment in a patient deterioration } \\
\text { simulation scenario: development of a situation awareness instrument. }\end{array}$ & 2016 & $\begin{array}{l}\text { Nurse Education } \\
\text { Today }\end{array}$ & $\begin{array}{l}\text { Quantitative, } \\
\text { exploratory and } \\
\text { descriptive }\end{array}$ & L6 \\
\hline $\begin{array}{l}\text { Boling } \mathrm{B} \text {, Pierce } \mathrm{MH}^{(28)} \\
\text { The effect of high-fidelity simulation on knowledge and confidence in } \\
\text { critical care training: An integrative review. }\end{array}$ & 2016 & $\begin{array}{l}\text { Nurse Education in } \\
\text { Practice }\end{array}$ & Integrative review & L6 \\
\hline $\begin{array}{l}\text { Jansson MM, Syrjala HP, Ohtonen PP, Merilainen MH, Kyngas HA, Ala-Kokko TI(29) } \\
\text { Randomized, controlled trial of the effectiveness of simulation education: A } \\
\text { 24-month follow-up study in a clinical setting. }\end{array}$ & 2015 & $\begin{array}{l}\text { American Journal of } \\
\text { Infection Control }\end{array}$ & $\begin{array}{l}\text { Randomized clinical } \\
\text { trial }\end{array}$ & L2 \\
\hline $\begin{array}{l}\text { Tsai AC, Krisciunas GP, Brook C, Gonzalez M, Crimlisk J, Silva J, Grillone GA }{ }^{(30)} \\
\text { Comprehensive emergency airway response team (EART) training and } \\
\text { education: impact on team effectiveness, personnel confidence, and protocol } \\
\text { knowledge. }\end{array}$ & 2015 & $\begin{array}{l}\text { Annals of Otology, } \\
\text { Rhinology \& } \\
\text { Laryngology }\end{array}$ & $\begin{array}{l}\text { Quantitative } \\
\text { descriptive }\end{array}$ & L6 \\
\hline $\begin{array}{l}\text { Alfes } C M \text {, Steiner } S L \text {, Manacci } \mathrm{CF}^{(31)} \\
\text { Critical care transport training: new strides in simulating the austere } \\
\text { environment. }\end{array}$ & 2015 & Air Medical Journal & Case report & L7 \\
\hline $\begin{array}{l}\text { Landsperger JS, Williams KJ, Hellervik SM, Chassan CB, Flemmons LN, } \\
\text { Davidson SR, et al.(32) } \\
\text { Implementation of a medical intensive care unit acute-care nurse } \\
\text { practitioner service. }\end{array}$ & 2015 & Hospital Practice & $\begin{array}{l}\text { Quantitative } \\
\text { descriptive }\end{array}$ & L6 \\
\hline $\begin{array}{l}\text { Baid } H, \text { Hargreaves } J^{(33)} \\
\text { Quality and safety: reflection on the implications for critical care nursing } \\
\text { education. }\end{array}$ & 2015 & $\begin{array}{l}\text { British Association of } \\
\text { Critical Care Nurses }\end{array}$ & Reflective analysis & L7 \\
\hline $\begin{array}{l}\text { Gundrosen S, Solligard E, Aadahl } P^{(34)} \\
\text { Team competence among nurses in an intensive care unit: the feasibility of } \\
\text { in situ simulation and assessing non-technical skills. }\end{array}$ & 2014 & $\begin{array}{l}\text { Intensive and Critical } \\
\text { Care Nursing }\end{array}$ & Case-control study & L3 \\
\hline $\begin{array}{l}\text { Calhoun AW, Boone MC, Dauer AK, Campbell DR, Montgomery VL }{ }^{(35)} \\
\text { Using simulation to investigate the impact of hours worked on task } \\
\text { performance in an Intensive Care Unit. }\end{array}$ & 2014 & $\begin{array}{l}\text { American Journal of } \\
\text { Critical Care }\end{array}$ & $\begin{array}{l}\text { Prospective } \\
\text { observational study }\end{array}$ & L3 \\
\hline $\begin{array}{l}\text { Jansson MM, Ala-Kokko TI, Ohtonen PP, Meriläinen } \mathrm{MH} \text {, Syrjälä } \mathrm{HP} \text {, Kyngäs } \mathrm{HA}^{(36)} \\
\text { Human patient simulation education in the nursing management of patients } \\
\text { requiring mechanical ventilation: a randomized, controlled trial. }\end{array}$ & 2014 & $\begin{array}{l}\text { American Journal of } \\
\text { Infection Control }\end{array}$ & $\begin{array}{l}\text { Randomized clinical } \\
\text { trial }\end{array}$ & L2 \\
\hline $\begin{array}{l}\text { Alinier } G \text {, Platt } A^{(37)} \\
\text { International overview of high-level simulation education initiatives in } \\
\text { relation to critical care. }\end{array}$ & 2013 & $\begin{array}{l}\text { British Association of } \\
\text { Critical Care Nurses }\end{array}$ & Literature review & L6 \\
\hline $\begin{array}{l}\text { Abe Y, Kawahara C, Yamashina A, Tsuboi } R^{(38)} \\
\text { Repeated scenario simulation to improve competency in critical care: a new } \\
\text { approach for nursing education. }\end{array}$ & 2013 & $\begin{array}{l}\text { American Journal of } \\
\text { Critical Care }\end{array}$ & $\begin{array}{l}\text { Prospective } \\
\text { observational study }\end{array}$ & L3 \\
\hline $\begin{array}{l}\text { Jansson } M, \text { Kääriäinen } M, \text { Kyngäs } \mathrm{H}^{(39)} \\
\text { Effectiveness of simulation-based education in critical care nurses' } \\
\text { continuing education: a systematic review. }\end{array}$ & 2013 & $\begin{array}{l}\text { Clinical Simulation in } \\
\text { Nursing }\end{array}$ & Systematic review & L1 \\
\hline $\begin{array}{l}\text { Mistry } \mathrm{V}^{(40)} \\
\text { Critical care training: using Twitter as a teaching tool. }\end{array}$ & 2011 & $\begin{array}{l}\text { British Journal of } \\
\quad \text { Nursing }\end{array}$ & Descriptive study & L6 \\
\hline $\begin{array}{l}\text { Mould J, White } \mathrm{H} \text {, Gallagher } \mathrm{R}^{(41)} \\
\text { Evaluation of a critical care simulation series for undergraduate nursing } \\
\text { students. }\end{array}$ & 2011 & Contemporary Nurse & $\begin{array}{l}\text { Descriptive } \\
\text { developmental }\end{array}$ & L6 \\
\hline $\begin{array}{l}\text { Ruth-Sahd LA, Schneider MA, Strouse } \mathrm{A}^{(42)} \\
\text { Fostering cultural and interdisciplinary awareness with "low-tech" simulation } \\
\text { in a fundamentals nursing course to prepare student nurses for critical care } \\
\text { clinical rotations. }\end{array}$ & 2011 & $\begin{array}{l}\text { Dimensions of } \\
\text { Critical Care Nursing }\end{array}$ & $\begin{array}{l}\text { Quantitative } \\
\text { descriptive }\end{array}$ & L6 \\
\hline $\begin{array}{l}\text { Shannon } \mathrm{SE} \text {, Long-Sutehall T, Coombs } \mathrm{M}^{(43)} \\
\text { Conversations in end-of-life care: communication tools for critical care } \\
\text { practitioners. }\end{array}$ & 2011 & $\begin{array}{l}\text { Nursing in Critical } \\
\text { Care }\end{array}$ & $\begin{array}{l}\text { Quantitative } \\
\text { descriptive }\end{array}$ & L6 \\
\hline $\begin{array}{l}\text { Cato } D, \text { Murray } M^{(44)} \\
\text { Use of simulation training in the Intensive Care Unit. }\end{array}$ & 2010 & Critical Care Nursing & Literature review & L6 \\
\hline $\begin{array}{l}\text { Barbosa SFF, Marin } \mathrm{HF}^{(45)} \\
\text { Simulação baseada na web: uma ferramenta para o ensino de enfermagem em } \\
\text { terapia intensiva. }\end{array}$ & 2009 & $\begin{array}{l}\text { Revista Latino- } \\
\text { Americana de } \\
\text { Enfermagem }\end{array}$ & Descriptive study & L6 \\
\hline $\begin{array}{l}\text { Bahouth MN, Esposito-Herr } \mathrm{MB}^{(46)} \\
\text { Orientation program for hospital-based nurse practitioners. }\end{array}$ & 2009 & $\begin{array}{l}\text { AACN Advanced } \\
\text { Critical Care }\end{array}$ & Qualitative descriptive & L6 \\
\hline
\end{tabular}


Chart 2 - Characterization of objectives and conclusions of articles on clinical simulation in Nursing Education in Intensive Care, published from 2008 to 2017

\begin{tabular}{|c|c|c|}
\hline Author(s), Year & Objective & Conclusions \\
\hline $\begin{array}{l}\text { Crowe S, Ewart L, Derman S(18) } \\
2017\end{array}$ & $\begin{array}{l}\text { To evaluate the impact of the use of simulation in } \\
\text { nursing education to increase the confidence and } \\
\text { knowledge of nurses, as well as improvement of the } \\
\text { outcome of patients in medical units of a hospital in } \\
\text { Canada. }\end{array}$ & $\begin{array}{l}\text { Simulation provided an environment that allowed } \\
\text { nurses the opportunity to explore and develop } \\
\text { critical thinking in clinical worsening situations, } \\
\text { resulting in increased knowledge and confidence to } \\
\text { assist patients in clinical worsening. }\end{array}$ \\
\hline $\begin{array}{l}\text { Sánchez-Expósito J, Costa CL, } \\
\text { Agea JLD, Izquierdo MDC, } \\
\text { Rodríguez DJ(19) } \\
2017\end{array}$ & $\begin{array}{l}\text { To analyze students' communication skills in interaction } \\
\text { with simulated critical patients. }\end{array}$ & $\begin{array}{l}\text { It has been shown that in settings with critically ill } \\
\text { patients, students tend to focus more on clinical } \\
\text { skills and advanced technology than on emotional or } \\
\text { communicative aspects when dealing with patients. }\end{array}$ \\
\hline $\begin{array}{l}\text { Karlsen MW, Gabrielsen AK, Falch } \\
\text { AL, Stubberud DG }{ }^{(20)} \\
2017\end{array}$ & $\begin{array}{l}\text { To explore the experiences of intensive care nursing } \\
\text { students with communication skills training in a } \\
\text { simulated environment. }\end{array}$ & $\begin{array}{l}\text { After the simulation course, students reported } \\
\text { better communication skills. The challenge is to } \\
\text { transfer the skills found in the setting to actual } \\
\text { patient care. }\end{array}$ \\
\hline $\begin{array}{l}\text { McRae ME, Chan A, Hulett R, Lee } \\
\text { AJ, Coleman B } \text { B }^{(21)} \\
2017\end{array}$ & $\begin{array}{l}\text { To test the effect of simulation on resuscitation in } \\
\text { cardiac surgery on the self-confidence of nurses and } \\
\text { their satisfaction with the simulation experience. }\end{array}$ & $\begin{array}{l}\text { The self-confidence scores for performing cardiac } \\
\text { and surgical resuscitation procedures were higher } \\
\text { after simulation. Nurses were highly satisfied after } \\
\text { simulation. }\end{array}$ \\
\hline $\begin{array}{l}\text { Smith JM, Van Aman MN, } \\
\text { Schneiderhahn ME, Edelman R, } \\
\text { Ercole PM } \text { PM }^{(2)} \\
2017\end{array}$ & $\begin{array}{l}\text { To evaluate the effectiveness of education for intensive } \\
\text { care nurses in the application of a tool to assess delirium } \\
\text { through clinical simulation. }\end{array}$ & $\begin{array}{l}\text { A multimodal educational strategy that included } \\
\text { simulation and significantly increased confidence in } \\
\text { the performance of the intensive care nurse in the } \\
\text { application of the delirium assessment scale in ICU. }\end{array}$ \\
\hline $\begin{array}{l}\text { Jansson MM, Syrjala HP, Ohtonen } \\
\text { PP, Merilainen MH, Kyngas HA, } \\
\text { Ala-Kokko TI(23) } \\
2017\end{array}$ & $\begin{array}{l}\text { To evaluate the longitudinal effects of simulation } \\
\text { education with structured debriefing and verbal } \\
\text { feedback on the knowledge and skills of intensive care } \\
\text { nurses in complying with current recommendations on } \\
\text { oral care. }\end{array}$ & $\begin{array}{l}\text { Single simulation education had only a minimal } \\
\text { effect on the knowledge and skills of intensive } \\
\text { care nurses to compliance with current oral care } \\
\text { recommendations. Despite greater awareness, there } \\
\text { was no significant difference in oral care practices } \\
\text { between study groups after simulation education. }\end{array}$ \\
\hline $\begin{array}{l}\text { Jansson MM, Syrjala HP, Ohtonen } \\
\text { PP, Merilainen MH, Kyngas HA, } \\
\text { Ala-Kokko TI(24) } \\
2017\end{array}$ & $\begin{array}{l}\text { To evaluate the longitudinal effects of simulation } \\
\text { education with structured debriefing and verbal } \\
\text { feedback on the knowledge and skills of endotracheal } \\
\text { suctioning of intensive care nurses. }\end{array}$ & $\begin{array}{l}\text { The unique simulation with structured debriefing } \\
\text { and verbal feedback was insufficient to change } \\
\text { the knowledge of intensive care nurses and } \\
\text { their abilities related to the care directive with } \\
\text { endotracheal aspiration. }\end{array}$ \\
\hline $\begin{array}{l}\text { Gordon CJ, Jorm C, Shulruf } \\
\text { B, Weller J, Currie J, Lim R, } \\
\text { Osomanski A }{ }^{(25)} \\
2016\end{array}$ & $\begin{array}{l}\text { To develop and evaluate a teamwork tool for health } \\
\text { students for their use in the context of emergency } \\
\text { response in a mass accident. }\end{array}$ & $\begin{array}{l}\text { These data provide evidence to support the validity } \\
\text { and reliability of the teamwork tool for nursing } \\
\text { students by helping them to identify the effective } \\
\text { attributes of teamwork. }\end{array}$ \\
\hline $\begin{array}{l}\text { Jansson MM, Syrjala HP, Ohtonen } \\
\text { PP, Merilainen MH, Kyngas HA, } \\
\text { Ala-Kokko TI(26) } \\
2016\end{array}$ & $\begin{array}{l}\text { To evaluate the knowledge and compliance of intensive } \\
\text { care nurses on hand hygiene through an intervention } \\
\text { and control group for simulation education. }\end{array}$ & $\begin{array}{l}\text { After a single education session, with the use of } \\
\text { simulation, the knowledge and compliance of } \\
\text { intensive care nurses on current hand hygiene } \\
\text { guidelines remained below expectations. }\end{array}$ \\
\hline $\begin{array}{l}\text { Lavoie P, Cossette S, Pepin J(27) } \\
2016\end{array}$ & $\begin{array}{l}\text { To develop and test a tool to measure the awareness of } \\
\text { the clinical worsening situation of nursing students in a } \\
\text { simulation setting. }\end{array}$ & $\begin{array}{l}\text { The tool appeared as a promising research tool, } \\
\text { although it still needs to be tested with other } \\
\text { populations and other simulation settings of clinical } \\
\text { worsening of patients. }\end{array}$ \\
\hline $\begin{array}{l}\text { Boling B, Pierce } \mathrm{MH}^{(28)} \\
2016\end{array}$ & $\begin{array}{l}\text { effect of simulation } \\
\text { fidence of the intensive }\end{array}$ & $\begin{array}{l}\text { High fidelity simulation is } \\
\text { knowledge and confiden } \\
\text { professionals, as well as c }\end{array}$ \\
\hline $\begin{array}{l}\text { Jansson MM, Syrjala HP, Ohtonen } \\
\text { PP, Merilainen MH, Kyngas HA, } \\
\text { Ala-Kokko TI(29) } \\
2015\end{array}$ & $\begin{array}{l}\text { To identify the effectiveness of simulation for the } \\
\text { education of nurses regarding the practice of the } \\
\text { guidelines to avoid complications associated with } \\
\text { intubation and mechanical ventilation. }\end{array}$ & $\begin{array}{l}\text { The skills of intensive care nurses to compliance with } \\
\text { evidence-based guidelines have improved in both } \\
\text { groups over time, but the improvements between } \\
\text { the study groups were significantly different only at } 6 \\
\text { months and were no longer evident after two years. }\end{array}$ \\
\hline $\begin{array}{l}\text { Tsai AC, Krisciunas GP, Brook C, } \\
\text { Gonzalez M, Crimlisk J, Silva J, } \\
\text { Grillone } \mathrm{GA}^{(30)} \\
2015\end{array}$ & $\begin{array}{l}\text { To evaluate the effectiveness and usefulness of } \\
\text { simulation for the Airway Emergency Response Team } \\
\text { at a tertiary hospital to improve team dynamics, } \\
\text { confidence and knowledge in obtaining an emergency } \\
\text { airway. }\end{array}$ & $\begin{array}{l}\text { It highlights the effectiveness and usefulness of } \\
\text { simulation in the evaluation of the team dynamics } \\
\text { and the confidence and levels of knowledge in the } \\
\text { settings of emergency airways. The professionals } \\
\text { benefited from simulation training. }\end{array}$ \\
\hline $\begin{array}{l}\text { Alfes CM, Steiner SL, Manacci } \\
\text { CF }^{(31)} \\
2015\end{array}$ & $\begin{array}{l}\text { To evaluate the use of high fidelity simulation as a tool } \\
\text { in the formation of interprofessional flight teams to } \\
\text { improve their skills and quality and to promote a safe } \\
\text { care for the patient during medical air transport. }\end{array}$ & $\begin{array}{l}\text { During simulation, flight students learned how to } \\
\text { manage critical conditions with available clinical } \\
\text { resources and perform advanced procedures on } \\
\text { the go. }\end{array}$ \\
\hline
\end{tabular}




\begin{tabular}{|c|c|c|}
\hline Author(s), Year & Objective & Conclusions \\
\hline $\begin{array}{l}\text { Landsperger JS, Williams KJ, } \\
\text { Hellervik SM, Chassan CB, Flemmons } \\
\text { LN, Davidson SR, et al. }{ }^{(32)} \\
2015\end{array}$ & $\begin{array}{l}\text { To describe the development of a service of nursing } \\
\text { professionals in a University Hospital in the Intensive } \\
\text { Care sector, designed to improve the reach and quality } \\
\text { of care. }\end{array}$ & $\begin{array}{l}\text { Not enough data were found to date to evaluate } \\
\text { cost savings. However, rigorous selection and } \\
\text { continuous training seem to qualify the Intensive } \\
\text { Care service. }\end{array}$ \\
\hline $\begin{array}{l}\text { Baid H, Hargreaves J }{ }^{(33)} \\
2015\end{array}$ & $\begin{array}{l}\text { To reflect on how an intensive care nursing course has } \\
\text { enabled nurses to offer high quality and safety nursing } \\
\text { care for critically ill patients and their families. }\end{array}$ & $\begin{array}{l}\text { Intensive nursing education can incorporate } \\
\text { simulation as a way to promote safe and high } \\
\text { quality clinical practices in the intensive care setting, } \\
\text { further enhancing patient care quality and safety. }\end{array}$ \\
\hline $\begin{array}{l}\text { Gundrosen S, Solligard E, Aadahl } \\
P^{(34)} \\
2014\end{array}$ & $\begin{array}{l}\text { To evaluate the feasibility of using an in situ simulation } \\
\text { model to explore the competence of the nursing team } \\
\text { in an ICU }\end{array}$ & $\begin{array}{l}\text { In situ simulation may be feasible to assess the } \\
\text { competence of intensive care practitioners, } \\
\text { appearing to be a promising tool for such use. }\end{array}$ \\
\hline $\begin{array}{l}\text { Calhoun AW, Boone MC, Dauer AK, } \\
\text { Campbell DR, Montgomery VL }{ }^{(35)} \\
2014\end{array}$ & $\begin{array}{l}\text { To explore the use of in situ simulation as an investigative } \\
\text { method, using it to examine the precision and time used } \\
\text { to perform tasks in intensive care nursing. }\end{array}$ & $\begin{array}{l}\text { Simulation can be effective to evaluate the time of } \\
\text { the nursing tasks and the training to perform these } \\
\text { tasks in intensive care. }\end{array}$ \\
\hline $\begin{array}{l}\text { Jansson MM, Ala-Kokko TI, } \\
\text { Ohtonen PP, Meriläinen MH, } \\
\text { Syrjälä HP, Kyngäs HA }{ }^{(36)} \\
2014\end{array}$ & $\begin{array}{l}\text { To evaluate the efficacy of simulation education of } \\
\text { human patients in the nursing management of patients } \\
\text { requiring mechanical ventilation. }\end{array}$ & $\begin{array}{l}\text { There was a significant transfer of skills learned to } \\
\text { clinical practice after simulation education, but } \\
\text { without influence on the participants' current level } \\
\text { of knowledge. }\end{array}$ \\
\hline $\begin{array}{l}\text { Alinier G, Platt } A^{(37)} \\
2013\end{array}$ & $\begin{array}{l}\text { To identify the emerging prevalence of the use of } \\
\text { simulation for education in order to improve patient } \\
\text { safety and the quality of nursing care in Intensive Care. }\end{array}$ & $\begin{array}{l}\text { The implementation of simulation in education } \\
\text { should be considered to ensure better educational } \\
\text { practices. }\end{array}$ \\
\hline $\begin{array}{l}\text { Abe Y, Kawahara C, Yamashina A, } \\
\text { Tsuboi R(38) } \\
2013\end{array}$ & $\begin{array}{l}\text { To evaluate the effectiveness of simulation-based } \\
\text { education in improving nursing care for critical } \\
\text { cardiovascular patients. }\end{array}$ & $\begin{array}{l}\text { The simulations approach seemed to not only } \\
\text { enhance technical skills of intensive care nurses, but } \\
\text { also their non-technical skills. }\end{array}$ \\
\hline $\begin{array}{l}\text { Jansson M, Kääriäinen M, Kyngäs } \\
\text { H }^{(39} \\
2013\end{array}$ & $\begin{array}{l}\text { To evaluate the state of the art on the effectiveness } \\
\text { of simulation-based education in the continuing } \\
\text { education of intensive care nurses with a focus on } \\
\text { knowledge and skills. }\end{array}$ & $\begin{array}{l}\text { The effect of simulation-based education on the } \\
\text { knowledge and skills of intensive care nurses is still } \\
\text { questionable for lack of published studies and solid } \\
\text { evidence. }\end{array}$ \\
\hline $\begin{array}{l}\text { Mistry V(40) } \\
2011\end{array}$ & $\begin{array}{l}\text { To explore the use of Twitter for simulation videos as a } \\
\text { teaching tool for nursing students, aimed at improving } \\
\text { reflection and clinical decision-making. }\end{array}$ & $\begin{array}{l}\text { The use of Twitter as an education tool is a } \\
\text { possibility, but it is little accepted and has inherent } \\
\text { limitations to its application in the context of } \\
\text { Intensive Care Education. }\end{array}$ \\
\hline $\begin{array}{l}\text { Mould J, White H, Gallagher R }{ }^{(41)} \\
2011\end{array}$ & $\begin{array}{l}\text { To evaluate the self-reported confidence and } \\
\text { competence of nursing students about the use of } \\
\text { critical patient simulation settings. }\end{array}$ & $\begin{array}{l}\text { Multi-setting simulations related to intensive } \\
\text { care practice are effective in improving student } \\
\text { confidence and competence. }\end{array}$ \\
\hline $\begin{array}{l}\text { Ruth-Sahd LA, Schneider MA, } \\
\text { Strouse } A^{(42)} \\
2011\end{array}$ & $\begin{array}{l}\text { To evaluate the effectiveness of nursing education } \\
\text { through the implementation of "low technology" } \\
\text { simulation to prepare nursing students to work in an } \\
\text { intensive care unit. }\end{array}$ & $\begin{array}{l}\text { The benefits of low-technology simulation for } \\
\text { nursing students are highlighted, preparing them to } \\
\text { work in an intensive care unit. }\end{array}$ \\
\hline $\begin{array}{l}\text { Shannon SE, Long-Sutehall T, } \\
\text { Coombs } \mathrm{M}^{(43)} \\
2011\end{array}$ & $\begin{array}{l}\text { To evaluate the effectiveness of the training of nurses } \\
\text { for the use of three communication tools, which can be } \\
\text { used in end-of-life care talks. }\end{array}$ & $\begin{array}{l}\text { The communication tools initially applied in simulation } \\
\text { are useful for nursing professionals, improving } \\
\text { communication and the skills inherent to it. }\end{array}$ \\
\hline $\begin{array}{l}\text { Cato D, Murray M(44) } \\
2010\end{array}$ & $\begin{array}{l}\text { To identify the use of high fidelity simulation for clinical } \\
\text { education and the development of skills of the ICU. }\end{array}$ & $\begin{array}{l}\text { Simulation provides a safe environment for making } \\
\text { mistakes, enabling the creation of settings for rare } \\
\text { or complex patients, ensuring the basic competence } \\
\text { required for intensive care nurses. }\end{array}$ \\
\hline $\begin{array}{l}\text { Barbosa SFF, Marin HF(45) } \\
2009\end{array}$ & $\begin{array}{l}\text { To develop and analyze the application of a clinical } \\
\text { simulation environment of nursing in Intensive Care, } \\
\text { via the internet, aiming to offer subsidies to improve } \\
\text { the quality of teaching in this field, helping students to } \\
\text { rescue critical thinking and question their own practice. }\end{array}$ & $\begin{array}{l}\text { It has been demonstrated the feasibility of } \\
\text { developing a simulation primarily focused on web- } \\
\text { based nursing undergraduate education and that } \\
\text { can present itself as a gateway to other educational } \\
\text { perspectives. }\end{array}$ \\
\hline $\begin{array}{l}\text { Bahouth MN, Esposito-Herr MB(46) } \\
2009\end{array}$ & $\begin{array}{l}\text { To describe the implementation of the Nursing } \\
\text { Professionals Orientation Program at the University of } \\
\text { Maryland's Medical Center in ICU, which aims to facilitate } \\
\text { the placement of new nurses in this sector of work. }\end{array}$ & $\begin{array}{l}\text { The consistent institution-wide guidance approach, } \\
\text { through the use of methodologies such as clinical } \\
\text { simulation, supports the successful transition to } \\
\text { care practice so that it is effective and safe. }\end{array}$ \\
\hline
\end{tabular}

\section{DISCUSSION}

The use of clinical simulation for training and qualification in Nursing related to care for critical patients has been of international interest; however, it is little studied in Brazil. This active teaching methodology has been shown to be effective for the qualification of ICU care in several countries ${ }^{(18,32-33,37-38,42,44)}$, training professionals and students in technical and non-technical skills, being a considerable tool for the qualification of care. It should be noted that most publications present a setting of exclusive training of professional nurses, not nursing staff. However, the evaluated abilities of the nurses cover the practices of the nursing 
team in care in Brazil, with this methodology being able to be considered for the improvement not only of the professional nurse, but also of the team in which it is integrated, being applicable to this heterogeneous group.

Among the skills required for nurses working in ICU, effective communication with staff and families has been an educational challenge. A study ${ }^{(19)}$ revealed through simulation setting that the communication skills of nursing students working together with critical patients are deficient, since these patients demonstrate interest in technologies and clinical complexities. On the other hand, when working in isolation, student communication improved after a specific course using the simulation methodology ${ }^{(20)}$. For nursing professionals, the training for the mobilization of communication skills was also effective, ensuring nurses the security to communicate adequately in their care routine, reducing harm to patients and increasing the satisfaction of family and staff( ${ }^{(43)}$.

Another variable evaluated and improved through ICU simulation was the development of critical thinking for accurate and efficient clinical decision-making. Simulation provides an environment that allows intensive care nurses the opportunity to explore and develop critical thinking in situations of patient worsening in a controlled and safe environment, increasing their knowledge and confidence ${ }^{(18)}$. In this context, simulation is more effective for learning than the first contact with the real critical situation, because it allows for the error and application of positive and negative feedback, giving nurses experience, security and ease of decision-making in real assistance situations, as well as improving ICU outcomes ${ }^{(28)}$. Thus, simulation becomes an indicated methodology to reach the increase in the quality of care and safety of critical patients ${ }^{(33)}$, in the sense of better preparing the professional to use his skills in the management of critical patients.

On the development of technical skills, such as knowledge, self-confidence and application of the technique itself, can be evaluated and improved through clinical simulation. Studies were performed considering the assistance of nurses in cardiac surgery resuscitation ${ }^{(21)}$, application of a tool to assess delirium in ICU ${ }^{(22)}$, knowledge and application of oral care ${ }^{(23)}$, endotracheal suctioning skills ${ }^{(24)}$, hands hygiene ${ }^{(26)}$, prevention of complications associated with endotracheal intubation and mechanical ventilation $^{(29)}$ and assessment of teamwork in emergency response of the airways ${ }^{(30)}$. The simulation tool was observed as effective for the development of such technical skills and improvement of the professional's self-confidence $e^{(21-22,30,36)}$ as it promotes to the nurses the application of the technique in a safe environment and as close as possible to the real work environment, allowing the feedback to improve the skill to be used in care. However, even though it is effective for the improvement of technical skills, studies have identified the need for repetition of the simulation activity, since when performed in a single dose it was not effective (23-24,26) $^{(26)}$ and, if not sequential, lost its effect on care after six months ${ }^{(29)}$.

In health education, the use of clinical simulation with debriefing is recognized as an essential methodology for the training of health professionals, however, reinforcing the findings of the studies included in the review, the need for continuous use of simulation is present. The practice in a simulation setting, followed by debriefing, promotes learning effectively and the improvement of technical skills, leadership and teamwork, and the debriefing is the closing of the simulation activity from discussion on positive points and points to be improved in the care given for the simulated patient ${ }^{(47)}$.

Another applicability of the simulation methodology is focused on the reproduction of critical settings, such as mass service ${ }^{(25)}$ and air transport of critical patients ${ }^{(31)}$. These situations require the aggregation of theoretical and practical knowledge, with traditional education insufficient to enable the development of skills for this assistance. The feasibility of reproduction of these events through clinical simulation promotes professional training, and it is also possible to use them to elaborate and validate protocols of these services ${ }^{(25)}$.

As for the process of professional evaluation and quality of care, simulation has been used for this purpose. Studies show that it is possible to select professionals for the ICU and to train them through clinical simulation ${ }^{(32,34)}$, guaranteeing quality to the services of intensive therapy. This tool is considered of great value for the selection and training of ICU professionals, for the provision of qualified and safe health care, and can be inserted in professional training programs of institutions and in the implementation of teams and new professionals in this sector ${ }^{(46)}$. In addition, it has been used to evaluate the accuracy and time spent on specific nursing tasks ${ }^{(35)}$, allowing managers to assess the professional competence, technologies used, conformation of care environments, as well as the review of the applied nursing process.

Studies have shown that the use of the Internet to subsidize students and nursing professionals has been used in association with the clinical simulation methodology, with the dissemination of simulation videos on the web ${ }^{(40,45)}$. The technological limitation of some institutions, remission time or the need for distance training can be supplied, thus, offering to students who will act in Intensive Therapy settings and video simulation practices, in which it becomes possible to carry out the evaluation of the setting and feedbacks of the conducts carried out, providing a discussion in the classroom and the development of critical thinking, being a gateway to other educational perspectives.

\section{Study limitations}

It is highlighted as a limitation of the study not to approach the technological and resource limitations for clinical simulation practices, which would still be a reality in Brazil. Even with the presence of randomized clinical trials, it is necessary to further investigate evidence of this issue in the international and, mainly, national territory.

\section{Contributions to the field of Nursing}

The contribution of the present study comes from the compilation of researches already done that demonstrate and evidence the use of clinical simulation in nursing education as an effective teaching methodology, considering it a tool for the qualification of care for critical patients.

\section{CONCLUSIONS}

The use of clinical simulation directed at critically ill patients has been used both for the continuing education of nursing teams and in undergraduate nursing education. It was considered 
an efficient tool for the improvement of the student and the nursing professional. There is a need for this methodology to be applied in a continuous, rather than unique way, so that its results. Variables that were analyzed after the use of simulation, such as confidence, communication skills, efficiency in identifying clinical worsening of patients, development of technical skills, teamwork and clinical decision-making, presented a significant improvement, demonstrating that the tool is effective in qualifying care for critical patients.

It is recommended to apply and expand in the national territory, since universities and health institutions have the subsidies to use this tool. Future research is stimulated in Brazil, evidencing the effectiveness of clinical simulation for the qualification of care for critical patients, increasing the national and international repository.

\section{REFERENCES}

1. Mendonça S, Basto ML, Ramos A. Nurse's strategies of clinical reasoning in critical care: a systematic review of literature. RIASE Online. 2017;2(3):692-709. doi: http://dx.doi.org/10.24902/r.riase.2016.2(3).754

2. Harmon MM, Thompson C. Clinical reasoning in pre-licensure nursing students. Teach Learn Nurs. 2015;10(2):63-70. doi: https://doi. org/10.1016/j.teln.2014.12.001

3. Carvalho EC, Oliveira-Kumakura ARS, Morais SCRV. Clinical reasoning in nursing: teaching strategies and assessment tools. Rev Bras Enferm. 2017;70(3):662-8. doi: https://doi.org/10.1590/0034-7167-2016-0509

4. Aebersold M, Tschannen D, Bathish M. Innovative simulation strategies in education. Nurs Res Practice. 2012;2012:1-7. doi: https://doi. org/10.1155/2012/765212

5. Barreto DG, Silva KGN, Moreira SSCR, Silva TS, Magro MCS. [Realistic simulation as a teaching strategy: an integrative review]. Rev Baiana Enferm[Internet]. 2014 [cited 2018 Jan 23];28(2):208-14. Available from: https://portalseer.ufba.br/index.php/enfermagem/article/ viewFile/8476/8874 Portuguese.

6. Negri EC, Mazzo A, Martins JCA, Pereira GA Jr, Almeida RGS, Pedersoli CE. Clinical simulation with dramatization: gains perceived by students and health professionals. Rev Lat Am Enferm. 2017;25:e2916. doi: https://doi.org/10.1590/1518-8345.1807.2916

7. Martins JCA, Mazzo A, Baptista RCN, Coutinho VRD, Godoy S, Mendes IAC, et al. The simulated clinical experience in nursing education: a historical review. Acta Paul Enferm. 2012;25(4):619-25. doi: https://doi.org/10.1590/\$0103-21002012000400022

8. Berragan L. Simulation: an effective pedagogical approach for nursing? Nurse Educ Today. 2011;31(7):660-3. doi: https://doi.org/10.1016/j. nedt.2011.01.019

9. Bensfield LA, Olech MJ, Horsley TL. Simulation for high-stakes evaluation in nursing. Nurse Educ. 2012;37(2):71-4. doi: https://doi. org/10.1097/NNE.0b013e3182461b8c

10. Garbuio CD, Oliveira SRA, Kameo YS, Melo SE, Dalri MCB, Carvalho EC. [Clinical simulation in nursing: experience report on the construction of a scenario]. Rev Enferm UFPE Online. 2016;10(8):3149-55. doi: https://doi.org/10.5205/reuol.9373-82134-1-RV1008201645 Portuguese.

11. Quirós SM, Vargas MAO. Clinical Simulation: a strategy that articulates teaching and research practices in nursing. Texto Contexto Enferm. 2014;23(4):815-6. doi: http://dx.doi.org/10.1590/0104-07072014001200edt

12. Dieckmann P, Lippert A, Glavia R, Rall M. When things do not go as expected: scenario life savers. Simul Healthc. 2010;5(4):219-25. doi: http://dx.doi.org/10.1097/SIH.0b013e3181e77f74

13. Souza MT, Silva MD, Carvalho R. Integrative review: what is it? How to do it? Einstein. 2010;8(1 Pt 1):102-6. doi: http://dx.doi.org/10.1590/ S1679-45082010RW1134

14. Whittemore R, Knafl K. The integrative review: updated methodology. J Adv Nurs. 2005;52(2):546-53. doi: http://dx.doi. org/10.1111/j.1365-2648.2005.03621.x

15. Mendes KDS, Silveira RCCP, Galvão CM. [Integrative literature review: a research method to incorporate evidence in health care and nursing]. Texto Contexto Enferm. 2008;17(4):758-64. doi: http://dx.doi.org/10.1590/\$0104-07072008000400018 Portuguese.

16. The Joanna Briggs Institute. Reviewers' Manual. Adelaide: JBI [Internet]; 2014 [cited 2018 Jan 21]. Available from: https://wiki.joannabriggs. org/display/MANUAL/Joanna+Briggs+Institute+Reviewer\%27s+Manual

17. Melnyk B, Fineout-Overholt E. Evidence-based practice in nursing and healthcare: a guide to best practice. 2nd. ed. Philadelphia: Lippincott, Williams \& Williams; 2011.

18. Crowe $S$, Ewart $L$, Derman $S$. The impact of simulation based education on nursing confidence, knowledge and patient outcomes on general medicine units. Nurse Educ Pract. 2017;29:70-5. doi: http://dx.doi.org/10.1016/j.nepr.2017.11.017

19. Sánchez-Expósito J, Costa CL, Agea JLD, Izquierdo MDC, Rodríguez DJ. Ensuring relational competency in critical care: importance of nursing students' communication skills. Intensive Crit Care Nurs. 2018;44:85-91. doi: http://dx.doi.org/10.1016/j.iccn.2017.08.010

20. Karlsen MW, Gabrielsen AK, Falch AL, Stubberud DG. Intensive care nursing students' perceptions of simulation for learning confirming communication skills: a descriptive qualitative study. Intens Crit Care Nurs. 2017;42:97-104. doi: http://dx.doi.org/10.1016/j.iccn.2017.04.005

21. McRae ME, Chan A, Hulett R, Lee AJ, Coleman B. The effectiveness of and satisfaction with high-fidelity simulation to teach cardiac surgical resuscitation skills to nurses. Intens Crit Care Nurs. 2017;40:64-9. doi: http://dx.doi.org/10.1016/j.iccn.2016.11.001 
22. Smith JM, Van Aman MN, Schneiderhahn ME, Edelman R, Ercole PM. Assessment of delirium in intensive care unit patients: educational strategies. J Contin Educ Nurs. 2017;48(5):239-44. doi: http://dx.doi.org/10.3928/00220124-20170418-09

23. Jansson MM, Syrjälä HP, Ohtonen PP, Merilainen MH, Kyngäs HA, Ala-Kokko TI. Effects of simulation education on oral care practices: a randomized controlled trial. Nurs Crit Care. 2017;22(3):161-8. doi: http://dx.doi.org/10.1111/nicc.12276

24. Jansson MM, Syrjälä HP, Ohtonen PP, Meriläinen MH, Kyngäs HA, Ala-Kokko TI. Longitudinal effects of single-dose simulation education with structured debriefing and verbal feedback on endotracheal suctioning knowledge and skills: a randomized controlled trial. Am J Infect Control. 2017;45(1):83-5. doi: http://dx.doi.org/10.1016/j.ajic.2016.05.032

25. Gordon CJ, Jorm C, Shulruf B, Weller J, Currie J, Lim R, Osomanski A. Development of a self-assessment teamwork tool for use by medical and nursing students. BMC Med Educ. 2016;16(1):218. doi: http://dx.doi.org/10.1186/s12909-016-0743-9

26. Jansson MM, Syrjala HP, Ohtonen PP, Merilainen MH, Kyngas HA, Ala-Kokko TI. Simulation education as a single intervention does not improve hand hygiene practices: a randomized controlled follow-up study. Am J Infect Control. 2016;44(6):625-30. doi: http://dx.doi. org/10.1016/j.ajic.2015.12.030

27. Lavoie $\mathrm{P}$, Cossette S, Pepin J. Testing nursing students' clinical judgment in a patient deterioration simulation scenario: development of a situation awareness instrument. Nurse Educ Today. 2016;38:61-7. doi: http://dx.doi.org/10.1016/j.nedt.2015.12.015

28. Boling $\mathrm{B}$, Pierce $\mathrm{MH}$. The effect of high-fidelity simulation on knowledge and confidence in critical care training: an integrative review. Nurse Educ Pract. 2016;16(1):287-93. doi: http://dx.doi.org/10.1016/j.nepr.2015.10.004

29. Jansson MM, Syrjala HP, Ohtonen PP, Merilainen MH, Kyngas HA, Ala-Kokko TI. Randomized, controlled trial of the effectiveness of simulation education: a 24-month follow-up study in a clinical setting. Am J Infect Control. 2016;44(4):387-93. doi: http://dx.doi.org/10.1016/j. ajic.2015.10.035

30. Tsai AC, Krisciunas GP, Brook C, Gonzalez M, Crimlisk J, Silva J, Grillone GA. Comprehensive emergency airway response team (EART) training and education: impact on team effectiveness, personnel confidence, and protocol knowledge. Ann Otol Rhinol Laryngol. 2016;125(6):45763. doi: http://dx.doi.org/10.1177/0003489415619178

31. Alfes CM, Steiner SL, Manacci CF. Critical care transport training: new strides in simulating the austere environment. Air Med J. 2015;34(4):186-7. doi: http://dx.doi.org/10.1016/j.amj.2015.03.006

32. Landsperger JS, Williams KJ, Hellervik SM, Chassan CB, Flemmons LN, Davidson SR, et al. Implementation of a medical intensive care unit acute-care nurse practitioner service. Hosp Pract. 2011;39(2):32-9. doi: http://dx.doi.org/10.3810/hp.2011.04.392

33. Baid H, Hargreaves J. Quality and safety: reflection on the implications for critical care nursing education. Nurs Crit Care. 2015;20(4):174-82. doi: http://dx.doi.org/10.1111/nicc.12182

34. Gundrosen S, Solligard E, Aadahl P. Team competence among nurses in an intensive care unit: the feasibility of in situ simulation and assessing non-technical skills. Intensive Crit Care Nurs. 2014;30(6):312-7. doi: http://dx.doi.org/10.1016/j.iccn.2014.06.007

35. Calhoun AW, Boone MC, Dauer AK, Campbell DR, Montgomery VL. Using simulation to investigate the impact of hours worked on task performance in an intensive care unit. Am J Crit Care. 2014;23(5):387-95. doi: http://dx.doi.org/10.4037/ajcc2014756

36. Jansson MM, Ala-Kokko TI, Ohtonen PP, Meriläinen MH, Syrjälä HP, Kyngäs HA. Human patient simulation education in the nursing management of patients requiring mechanical ventilation: a randomized, controlled trial. Am J Infect Control. 2014;42(3):271-6. doi: http:// dx.doi.org/10.1016/j.ajic.2013.11.023

37. Alinier G, Platt A. International overview of high-level simulation education initiatives in relation to critical care. Nurs Crit Care. 2014;19(1):42-9. doi: http://dx.doi.org/10.1111/nicc.12030

38. Abe Y, Kawahara C, Yamashina A, Tsuboi R. Repeated scenario simulation to improve competency in critical care: a new approach for nursing education. Am J Crit Care. 2013;22(1):33-40. doi: http://dx.doi.org/10.4037/ajcc2013229

39. Jansson $M$, Kääriäinen $M$, Kyngäs $H$. Effectiveness of simulation-based education in critical care nurses' continuing education: a systematic review. Clin Simul Nurs. 2013;9(9):e355-e360. doi: https://doi.org/10.1016/j.ecns.2012.07.003

40. Mistry V. Critical care training: using twitter as a teaching tool. Br J Nurs. 2011;20(20):1292-6. doi: http://dx.doi.org/10.12968/ bjon.2011.20.20.1292

41. Mould J, White H, Gallagher R. Evaluation of a critical care simulation series for undergraduate nursing students. Contemp Nurse. 2011;38(12):180-90. doi: http://dx.doi.org/10.5172/conu.2011.38.1-2.180

42. Ruth-Sahd LA, Schneider MA, Strouse A. Fostering cultural and interdisciplinary awareness with "low-tech" simulation in a fundamentals nursing course to prepare student nurses for critical care clinical rotations. Dimens Crit Care Nurs. 2011; 30(5):263-8. doi: http://dx.doi. org/10.1097/DCC.0b013e318227717e

43. Shannon SE, Long-Sutehall T, Coombs M. Conversations in end-of-life care: communication tools for critical care practitioners. Nurs Crit Care. 2011;16(3):124-30. doi: http://dx.doi.org/10.1111/j.1478-5153.2011.00456.x

44. Cato D, Murray M. Use of simulation training in the intensive care unit. Crit Care Nurs Q [Internet]. 2010;33(1):44-51. doi: http://dx.doi. org/10.1097/CNQ.0b013e3181c8dfd4

45. Barbosa SFF, Marin HF. Web-based simulation: a tool for teaching critical care nursing. Rev Latino-Am Enfermagem. 2009;17(1):7-13. doi: http://dx.doi.org/10.1590/S0104-11692009000100002 
46. Bahouth MN, Esposito-Herr MB. Orientation program for hospital-based nurse practitioners. Advanced Critical Care. 2009;20(1):82-90. doi: http://dx.doi.org/10.1097/NCl.0b013e3181945422

47. Taras J, Everett T. Rapid cycle deliberate practice in medical education: a systematic review. Cureus. 2017;9(4):e1180. doi: http://dx.doi. org/10.7759/cureus.1180 